\title{
In Situ Evaluation of Fludarabine-DNA Interaction Using a DNA-Electrochemical Biosensor
}

\author{
H. Eda Satana ${ }^{1,2}$ and Ana Maria Oliveira-Brett ${ }^{1}$ \\ ${ }^{1}$ Departamento de Química, Faculdade de Ciências e Tecnologia, Universidade de Coimbra, 3004-535 Coimbra, Portugal \\ ${ }^{2}$ Department of Analytical Chemistry, Faculty of Pharmacy, Gazi University, Etiler, 06330 Ankara, Turkey
}

Correspondence should be addressed to Ana Maria Oliveira-Brett, brett@ci.uc.pt

Received 25 January 2011; Accepted 23 February 2011

Academic Editor: Bengi Uslu

Copyright (C) 2011 H. Eda Satana and A. M. Oliveira-Brett. This is an open access article distributed under the Creative Commons Attribution License, which permits unrestricted use, distribution, and reproduction in any medium, provided the original work is properly cited.

\begin{abstract}
Fludarabine, 9- $\beta$-D-arabinosyl-2-fluoroadenine, the nucleoside analog, represents a highly effective treatment for hairy cell leukemia. The electrochemical behaviour of fludarabine is an irreversible diffusion controlled oxidation mechanism and was investigated at a glassy carbon electrode in different supporting electrolytes using cyclic, differential pulse, and square wave voltammetry. The diffusion coefficient of fludarabine was calculated to be $D_{\mathrm{FLU}}=1.71 \times 10^{-6} \mathrm{~cm}^{2} \mathrm{~s}^{-1}$ in $\mathrm{pH} 7.00 .1 \mathrm{M}$ phosphate buffer. The oxidation mechanism of fludarabine occurs with the transfer of one proton and one electron and the formation of a hydroxylated species. The interaction of fludarabine with DNA was investigated, by differential pulse voltammetry, in incubated solutions and using dsDNA- and polyhomonucleotides-, poly[G] and poly[A], electrochemical biosensors. The results showed that fludarabine interacts with DNA causing changes in the DNA structure.
\end{abstract}

\section{Introduction}

Nucleotides are essential components of the signal transduction system and energy providers such as adenosine tri phosphate (ATP). Nucleoside analogs are antimetabolites used in cellular and molecular biology research, as well as in the treatment of some diseases as antiviral or anticancer drugs. These analogs are metabolized to pharmacologically active derivatives in cells and compete with natural products.

The nucleoside analog fludarabine (FLU, 9- $\beta$-D-arabinosyl-2-fluoroadenine), Scheme 1, represents a highly effective treatment for hairy cell leukemia, chronic lymphocytic leukaemia, and other several hematopoietic malignancies [1]. The introduction of a fluorine atom in the nucleoside group has improved the pharmacological properties of the molecule with minor stereochemistry changes. Unlike the former nucleoside analogs, FLU is resistant to deamination by adenosine deaminase. After entering the cells by means of specific nucleoside transporters, FLU is activated to its phosphorylated derivative by intracellular kinase. Its active metabolite competes with deoxy-ATP for incorporation into the growing nucleic acid chain causing disruption of nucleic acid synthesis. In the same way, this metabolite interrupts the elongation of the RNA primer strand [2].

To improve treatment results in patients, individualization of FLU dosing is important. This individualization must be depended on correlations between dosing and plasma concentration of drug and its derivatives. Furthermore, the determination of cellular concentrations of FLU could provide valuable information for understanding the mechanisms of DNA damage and cell death. Therefore, some methods based on high performance liquid chromatographic and voltammetric techniques were developed for the determination of FLU especially in biological samples. FLU and its triphosphate derivative were determined by liquid chromatography with UV detection [3-7] and with tandem mass spectrometry [8] in human cells, urine, plasma, and pharmaceuticals, and the electrochemical behaviour of FLU was also investigated using pyrolytic graphite electrode [9].

Most studies were related with the pharmacological character and effects of FLU on biological molecules, carried out in cell lines, and several studies indicated that FLU is an agent that causes disruption or breakages in the genetic material. 


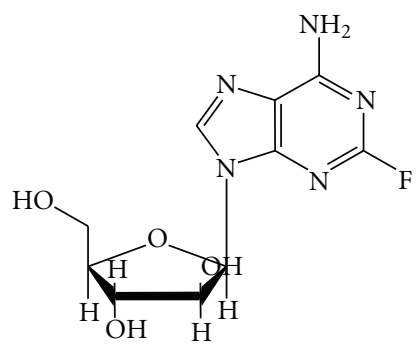

Scheme 1: Chemical structure of fludarabine.

Deoxyribonucleic acid (DNA) is the genetic material and has important biological roles including transcription of the genetic information, signalling, and metabolic regulation. Formation of DNA strand breaks causes chromosome aberrations and accumulation of these mutations and other DNA damages increase carcinogenic or teratogenic risks. Finally, these events may result in a malignant transformation or cell death. Due to their important biological and genetic roles, nucleic acids have been intensively studied and a number of different techniques have been developed to elucidate various aspects of DNA and RNA structures and properties. Electrochemical methods including DNA-electrochemical biosensors comprise an important group of these techniques. Compared with optical devices, electrochemical sensors have some advantages such as their high sensitivity, simplicity, low cost, and fast response time [10-13].

A DNA-electrochemical biosensor consists of an electrode with DNA immobilized on the surface. Interaction of a damaging agent with DNA causes changing of electrochemical properties of the DNA recognition layer. This effect is turned to measurable electrical signals and DNA damage and interaction caused by hazardous compounds, such as metals or pharmaceutical drugs, can be determined.

In this study, the electrochemical oxidation of FLU and the mechanism of FLU-dsDNA and polyhomonucleotides, poly[G] and poly[A], interaction were carried out using cyclic, square wave and differential pulse voltammetry at a glassy carbon electrode. The results will contribute to the clarification of the mechanism by which FLU can cause direct in vivo DNA damage.

\section{Experimental}

2.1. Materials and Reagents. Fludarabine, double stranded (dsDNA), polyadenylic acid (Poly[A]), and polyguanylic acid (Poly[G]) were obtained from Sigma and used without further purification. A stock solution of $1 \mathrm{mM}$ FLU was prepared in deionized water and stored at $5^{\circ} \mathrm{C}$.

Solutions of different concentrations of FLU were prepared by dilution of the appropriate quantity in supporting electrolyte. Stock solutions of $186 \mu \mathrm{g} \mathrm{mL}^{-1}$ dsDNA, $477 \mu \mathrm{g} \mathrm{mL}^{-1}$ Poly[G], and $587 \mu \mathrm{g} \mathrm{mL}^{-1}$ Poly[A] were prepared in deionized water and diluted to the desired concentrations in $\mathrm{pH} 4.50 .1 \mathrm{M}$ acetate buffer.
TABLE 1: Supporting electrolyte buffer solutions.

\begin{tabular}{lc}
\hline $\mathrm{pH}$ & Composition \\
\hline 2.1 & $\mathrm{HCl}+\mathrm{KCl}$ \\
3.4 & $\mathrm{HAcO}+\mathrm{NaAcO}$ \\
4.3 & $\mathrm{HAcO}+\mathrm{NaAcO}$ \\
4.5 & $\mathrm{HAcO}+\mathrm{NaAcO}$ \\
5.4 & $\mathrm{HAcO}+\mathrm{NaAcO}$ \\
6.1 & $\mathrm{NaH}_{2} \mathrm{PO}_{4}+\mathrm{Na}_{2} \mathrm{HPO}_{4}$ \\
7.0 & $\mathrm{NaH}_{2} \mathrm{PO}_{4}+\mathrm{Na}_{2} \mathrm{HPO}_{4}$ \\
8.0 & $\mathrm{NaH}_{2} \mathrm{PO}_{4}+\mathrm{Na}_{2} \mathrm{HPO}_{4}$ \\
9.2 & $\mathrm{NH}_{3}+\mathrm{NH}_{4} \mathrm{Cl}$ \\
10.5 & $\mathrm{NH}_{3}+\mathrm{NH}_{4} \mathrm{Cl}$ \\
12.0 & $\mathrm{NaOH}^{\mathrm{KCl}}$ \\
\hline
\end{tabular}

All supporting electrolyte solutions (Table 1) were prepared using analytical grade reagents and purified water from a Millipore Milli-Q system (conductivity $\leq 0.1 \mu \mathrm{S} \mathrm{cm}^{-1}$ ).

2.2. Apparatus. Voltammetric experiments were carried out using a $\mu$ Autolab running with GPES 4.9 software, EcoChemie, Utrecht, The Netherlands. Measurements were carried out using a three-electrode system in a $0.5 \mathrm{~mL}$ one-compartment electrochemical cell (Cypress System Inc., USA). Glassy carbon electrode (GCE, $d=1.5 \mathrm{~mm}$ ) was the working electrode, Pt wire the counter electrode, and $\mathrm{Ag} / \mathrm{AgCl}(3 \mathrm{M} \mathrm{KCl})$ the reference electrode.

The $\mathrm{pH}$ measurements were carried out with a Crison micropH $2001 \mathrm{pH}$-meter with an Ingold combined glass electrode. All experiments were done at room temperature $\left(25 \pm 1^{\circ} \mathrm{C}\right)$ and, microvolumes were measured using EP10 and EP-100 Plus Motorized Microliter Pippettes (Rainin Instrument Co. Inc., Woburn, USA).

The experimental conditions for differential pulse (DP) voltammetry were: pulse amplitude $50 \mathrm{mV}$, pulse width $70 \mathrm{~ms}$, and scan rate $5 \mathrm{mV} \mathrm{s}^{-1}$. For square wave (SW) voltammetry, a frequency of $50 \mathrm{~Hz}$ and a potential increment of $2 \mathrm{mV}$, corresponding to an effective scan rate of $100 \mathrm{mV} \mathrm{s}^{-1}$ were used.

The GCE was polished using diamond spray (particle size $3 \mu \mathrm{m}$ ) (Kemet, UK) before each electrochemical experiment. After polishing, it was rinsed thoroughly with Milli-Q water. Following this mechanical treatment, the GCE was placed in buffer supporting electrolyte and voltammograms were recorded until a steady-state baseline voltammogram was obtained. This procedure ensured very reproducible experimental results.

2.3. Acquisition and Presentation of Voltammetric Data. All the voltammograms presented were background-subtracted and baseline-corrected using the moving average application with a step window of $5 \mathrm{mV}$ included in GPES version 4.9 software. This mathematical treatment improves the visualization and identification of peaks over the baseline without introducing any artifact, although the peak intensity is, in some cases, reduced $(<10 \%)$ relative to that of the 


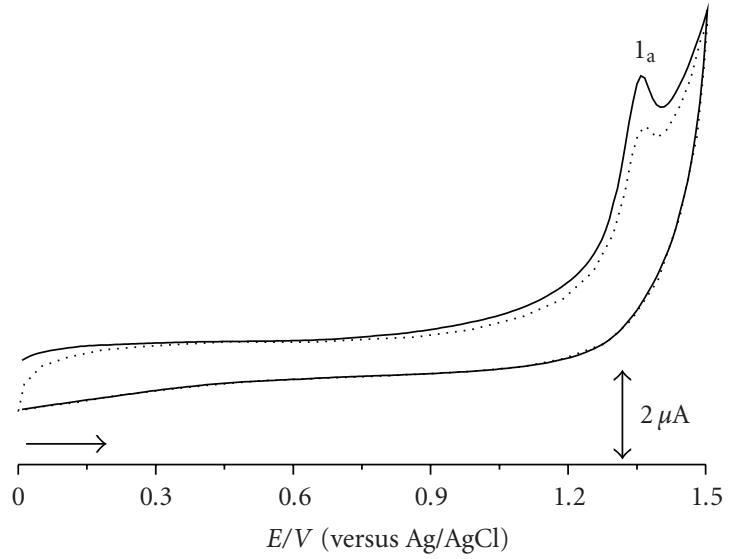

Figure 1: Cyclic voltammograms of $100 \mu \mathrm{M}$ FLU in $\mathrm{pH} 6.10 .1 \mathrm{M}$ phosphate buffer solution, $\mathrm{N}_{2}$ saturated; "solid line" first scan, "dotted line" second scan, and $v=100 \mathrm{mV} \mathrm{s}^{-1}$.

untreated curve. Nevertheless, this mathematical treatment of the original voltammograms was used in the presentation of all experimental voltammograms for a better and clearer identification of the peaks. The values for peak current presented in all plots were determined from the original untreated voltammograms after subtraction of the baseline.

\subsection{Incubation Procedure and DNA-Electrochemical Biosensor} Preparation. In order to perform the incubation procedure in $\mathrm{pH} 4.50 .1 \mathrm{M}$ acetate buffer, $100 \mu \mathrm{g} \mathrm{mL}^{-1} \mathrm{dsDNA}$ were mixed with $2 \mu \mathrm{M}$ FLU and $100 \mu \mathrm{g} \mathrm{mL}^{-1}$ Poly[G] or Poly[A] were mixed with $5 \mu \mathrm{M}$ FLU, and then incubated during different periods at room temperature. Control solutions of FLU, dsDNA, Poly[G], and Poly[A] in pH 4.5 0.1 M acetate buffer were also prepared and stored during the same periods in similar conditions as the FLU-dsDNA, FLU-Poly[G], and FLU-Poly[A] incubated solutions.

The thin layer dsDNA-modified electrode was prepared with three drops of $5 \mu \mathrm{L}$ each containing $50 \mu \mathrm{g} \mathrm{mL}^{-1}$ dsDNA. After setting each drop on the electrode surface, the biosensor was allowed to dry under the constant flux of $\mathrm{N}_{2}$. The dsDNA-electrochemical biosensor was incubated in $50 \mu \mathrm{M}$ FLU solution during different times. Then, in order to remove unbound FLU molecules from the surface, the electrode was carefully rinsed with deionized water and transferred to supporting electrolyte. After each measurement, the dsDNA film was removed from the electrode surface and a new biosensor was prepared for each experiment.

Poly[G]- and Poly[A]-electrochemical biosensors were prepared placing three drops of $5 \mu \mathrm{L}$ each containing $25 \mu \mathrm{g} \mathrm{mL}^{-1}$ of each polyhomonucleotide on the electrode surface.

\section{Results and Discussion}

The electrochemical behaviour of FLU was investigated using the glassy carbon electrode (GCE) and cyclic (CV), differential pulse (DP), and square wave (SW) voltammetry.
Systematic studies to explain the mechanism of interaction of FLU with dsDNA, Poly[A], and Poly[G] were carried out, with the multilayer modified electrodes or in incubated solutions, using the GCE and DP voltammetry. DP voltammetry, due of its high sensitivity, enabled the detection of minor changes on the DNA double helical structure and DNA oxidative damage.

\subsection{Electro-Oxidation of Fludarabine}

3.1.1. Cyclic Voltammetry. The CV of $100 \mu \mathrm{M}$ FLU at a GCE, in pH $6.10 .1 \mathrm{M}$ phosphate buffer, showed one anodic peak $1_{\mathrm{a}}$, at $E_{\mathrm{pa}}^{1}=+1.36 \mathrm{~V}$, Figure 1 . Reversing the potential no reduction peak was observed, indicating that the oxidation process was irreversible, and peak $1_{\mathrm{a}}$ current decreased with increasing number of scans due to FLU and/or its oxidation product adsorption on the GCE surface.

The effect of $\mathrm{pH}$ on the electrochemical oxidation behaviour of FLU was investigated in aqueous buffered solutions in the range $2<\mathrm{pH}<12$. CVs showed that in strong acidic buffer solutions, $\mathrm{pH} \leq 2$, no FLU oxidation peak was observed. For $\mathrm{pH}>2$, the $\mathrm{CVs}$ showed irreversible peak $1_{\mathrm{a}}$. The oxidation process was $\mathrm{pH}$-dependent, and the peak potentials of FLU shifted, with increasing $\mathrm{pH}$.

The effect of the scan rate in a $100 \mu \mathrm{M}$ FLU solution, in $\mathrm{N}_{2}$ saturated $\mathrm{pH}$ 6.1 $0.1 \mathrm{M}$ phosphate buffer, between 5 and $500 \mathrm{mV} \mathrm{s}^{-1}$ was also investigated. Increasing the scan rate, the peak $1_{a}$ potential was slightly shifted to more positive potentials, and $\left|E_{\mathrm{pa}}-E_{\mathrm{p} / 2 \mathrm{a}}\right|=\sim 33 \mathrm{mV}$. Since for a diffusioncontrolled irreversible system $\left|E_{\mathrm{pa}}-E_{\mathrm{p} / 2 \mathrm{a}}\right|=47.7 /\left(\alpha_{\mathrm{a}} n^{\prime}\right)$ where $\alpha_{\mathrm{a}}$ is the charge transfer coefficient and $n^{\prime}$ the number of electrons in the rate-determining step [14], it was calculated the value of $\alpha_{\mathrm{a}} n^{\prime}=1.8$.

Increasing the scan rate the peak $1_{\mathrm{a}}$ current increased linearly with square root of $v$, indicating a diffusion controlled behaviour of FLU. The peak current for a diffusioncontrolled irreversible system is given by $I_{\mathrm{pa}}(\mathrm{A})=-2.99 \times$ $10^{5} n\left(\alpha_{\mathrm{a}} n^{\prime}\right)_{1 / 2} \mathrm{~A}[\mathrm{O}]_{\infty} D_{O}^{1 / 2} \nu^{1 / 2}$ where $n$ is the number of the electrons transferred during the oxidation of FLU $(n=1$ as shown Section 3.1.2), $\mathrm{A}$ is the electrode area in $\mathrm{cm}^{2}$, $D_{O}$ is the diffusion coefficient in $\mathrm{cm}^{2} \mathrm{~s}^{-1},[O]_{\infty}$ is the concentration in $\mathrm{mol} \mathrm{cm}^{-3}$, and $v$ is in $\mathrm{V} \mathrm{s}^{-1}$ [14]. The GCE electroactive area of $\mathrm{A}=0.00691 \mathrm{~cm}^{2}$ was determined as described elsewhere [15]. By plotting $I_{\mathrm{pc}}$ versus $\nu^{1 / 2}$, the value of $D_{O}$ was obtained from the slope $-3.04 \times 10^{-7} \mathrm{~A}$ $\left(\mathrm{V} \mathrm{s}^{-1}\right)^{-1 / 2}$. The diffusion coefficient of FLU was calculated to be $D_{\mathrm{FLU}}=1.71 \times 10^{-6} \mathrm{~cm}^{2} \mathrm{~s}^{-1}$.

3.1.2. Differential Pulse Voltammetry. DP voltammetry was used to investigate the effect of $\mathrm{pH}$ on the electrochemical oxidation of $100 \mu \mathrm{M} \mathrm{FLU}$, and peak $1_{\mathrm{a}}$, in aqueous supporting electrolytes over a $\mathrm{pH}$ range from 2.0 to 12.0 , Figure 2(a). As already found by $\mathrm{CV}$, in strong acidic buffer solution, no FLU oxidation peak was observed.

The peak $1_{\mathrm{a}}$ potential shifted linearly with $\mathrm{pH}$ towards more negative values and peak current increased up to $\mathrm{pH}$ 6.1 and afterwards decreased with increasing $\mathrm{pH}$, Figure 2(b). The relationship was linear following the equation 


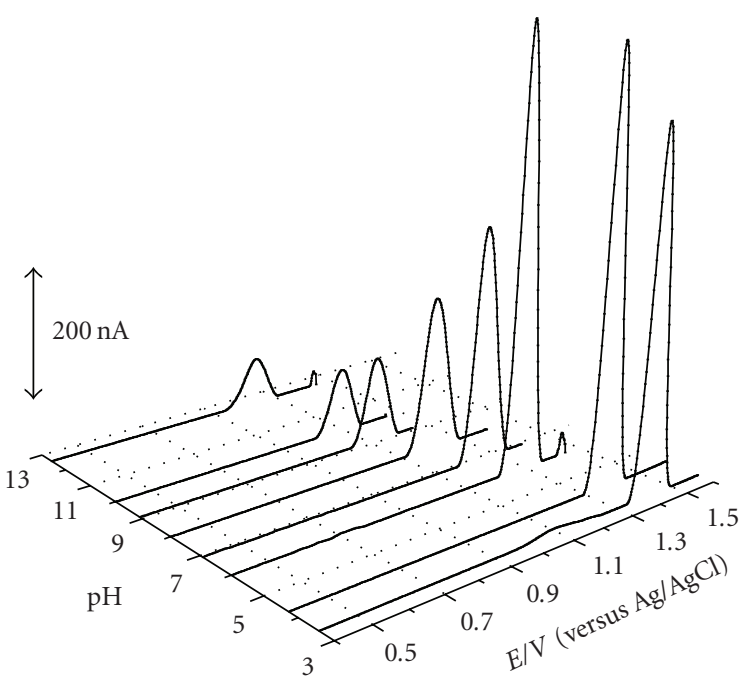

(a)

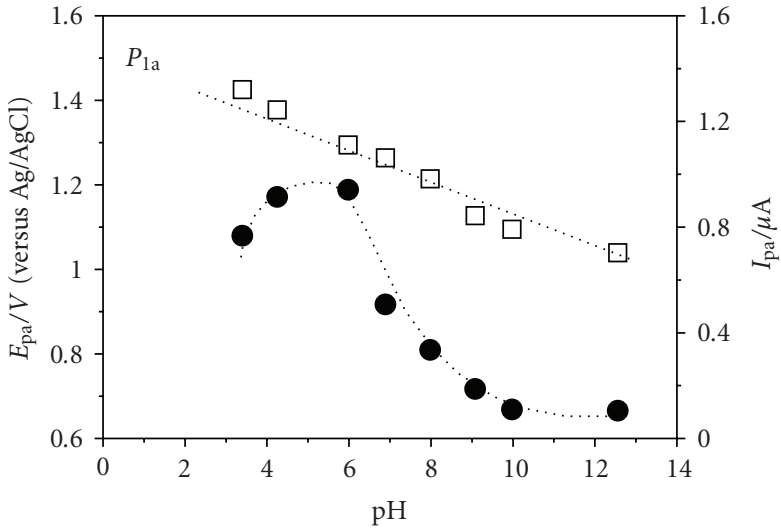

(b)

Figure 2: (a) 3D plots of baseline corrected DP voltammograms in $100 \mu \mathrm{M}$ FLU (b) Plot of peak $1_{\mathrm{a}}:(\square) E_{\mathrm{pa}}$ and (•) $I_{\mathrm{pa}}$ versus pH. Dotted line corresponds to $59 \mathrm{mV}$ per $\mathrm{pH}$ unit.

$E_{\mathrm{pa}}(\mathrm{mV})=1.48-0.06 \mathrm{pH}$, Figure 2(b). The slope of the line, $-59 \mathrm{mV}$ per $\mathrm{pH}$ unit, shows that the mechanism of oxidation involves the same number of electrons and protons. The number of electrons transferred, $n$, was determined by the peak width at half height, $W_{1 / 2} \sim 75 \mathrm{mV}$ and is close to the theoretical value of $90 \mathrm{mV}$, corresponding to an electrochemical reaction involving the transfer of one electron.

According to these results, the oxidation of FLU occurs with a transfer of one electron and one proton to produce a finally hydroxylated product. Since FLU is an adenine analogue, the irreversible oxidation mechanism is similar to adenine.

Successive scans in the same solution, without cleaning the electrode, showed the decrease of peak $1_{\mathrm{a}}$ current and the occurrence of oxidation peak $2_{\mathrm{a}}$, at $E_{\mathrm{p}}=+0.33 \mathrm{~V}$, corresponding to the oxidation of FLU oxidation product.

The effect of $\mathrm{pH}$ on the electrochemical oxidation behaviour of peak 2 a showed that with increasing $\mathrm{pH}$, peak 2 a shifted to less positive potentials, and a linear relationship, with the slope of the $E_{\mathrm{pa}}$ versus $\mathrm{pH}$ of $-59 \mathrm{mV}$ per $\mathrm{pH}$ unit, was found corresponding to the transfer of the same number of electron and proton in aqueous buffer solution.

3.1.3. Square Wave Voltammetry. The electrochemical behaviour of FLU was also investigated using SW voltammetry due to the its advantages such as fast analysis time, lower blocking of electrode surface by the species, and less consumption of analyte. This method enables to detect during only one scan whether the electron transfer reaction is reversible or not. Due to the sampling of current values in both positive and negative going pulses, peaks belonging to the oxidation and reduction of the species at the electrode surface can be obtained simultaneously.
SW voltammetric experiments were carried out in the same $\mathrm{pH}$ range as $\mathrm{CV}$ and DP voltammetry. The oxidation peak $1_{\mathrm{a}}$ was observed in all buffer solutions, and its irreversibility was confirmed by plotting the forward and backward components of the total current obtained in solutions of $100 \mu \mathrm{M}$ FLU in pH 6.1 0.1 M phosphate buffer, Figure 3(a). The results obtained on the second and subsequent scans in the same solution without cleaning electrode showed the second oxidation peak 2 a, at $E_{\mathrm{pa}}=+0.33 \mathrm{~V}$, related to the oxidation of FLU oxidation product, Figure 3(b). Since reduction and oxidation currents were equal, the reversibility of the second peak was confirmed.

3.1.4. Analytical Determination of Fludarabine. DP voltammetry was used for the electroanalytical determination of FLU due to its advantages such as good discrimination, low detection limit, and short analysis time. According to Figure 2, the best $\mathrm{pH}$ was $\mathrm{pH}$ 6.1 0.1 M phosphate buffer and linearity range was achieved between 0.99 and $14.8 \mu \mathrm{M}$ FLU, Table 2. Above this range, due to the adsorption of FLU or its oxidation product on the GCE surface, a loss of linearity was observed. In order to ensure a clean electrode surface and to avoid the adsorption of FLU and/or its oxidation product, the GCE surface was always cleaned between each measurement. The detection limit (LOD) and quantification limit (LOQ) were calculated according to the $3 \mathrm{~s} / \mathrm{m}$ and $10 \mathrm{~s} / \mathrm{m},[16,17]$, where $s$ is the standard deviation of the peak current, $m$ is slope of calibration curve, and LOD $=0.28 \mu \mathrm{M}$ and LOQ $=0.94 \mu \mathrm{M}$ were found, Table 2 .

3.2. DNA-Fludarabine Interaction. FLU was synthesized as an adenosine nucleoside analogue and used in the treatment of leukemia. After intravenous infusion, FLU is transported to cell by means of transporters, inhibits DNA synthesis, 
TABLE 2: Regression and validation data of calibration line of fludarabine.

\begin{tabular}{lcccccccc}
\hline Potential & $\begin{array}{c}\text { Linearity } \\
\text { range }(\mu \mathrm{M})\end{array}$ & Slope & Intercept & $\begin{array}{c}\text { Correlation } \\
\text { coefficient }\end{array}$ & LOD $(\mu \mathrm{M})$ & LOQ $(\mu \mathrm{M})$ & $\begin{array}{c}\text { Repeatability of peak } \\
\text { current (RSD\%) }\end{array}$ & $\begin{array}{c}\text { Repeatability of peak } \\
\text { potential (RSD\%) }\end{array}$ \\
\hline 1.28 & $1.6-14.8$ & $1.56 \times 10^{-8}$ & $1.29 \times 10^{-8}$ & 0.9993 & 0.28 & 0.94 & 1.55 & 0.09 \\
\hline
\end{tabular}

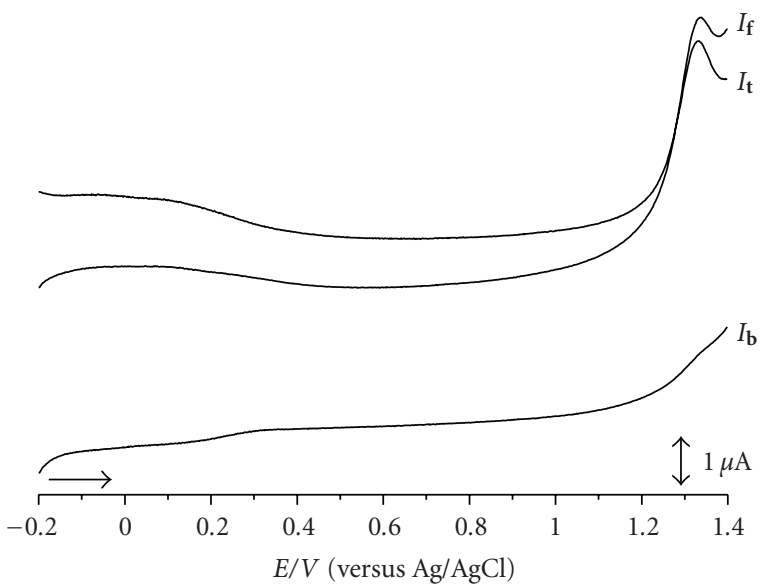

(a)
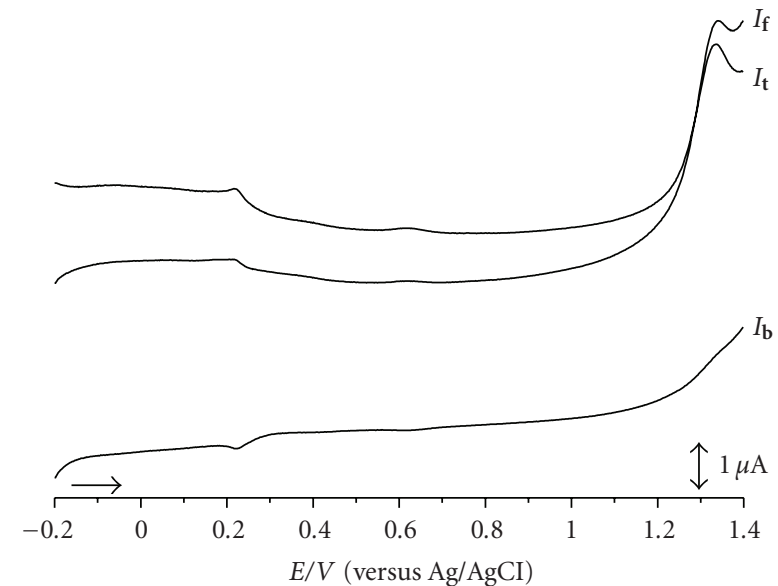

(b)

Figure 3: SW voltammograms of $100 \mu \mathrm{M}$ FLU in $\mathrm{pH} 6.10 .1 \mathrm{M}$ phosphate buffer: (a) first scan, (b) second scan, $f=50 \mathrm{~Hz}, \Delta E_{\mathrm{s}}=2 \mathrm{mV}$, ${ }^{1}$ pulse amplitude $100 \mathrm{mV}, I_{\mathrm{t}}$ - total, $I_{\mathrm{f}}$-forward and $I_{\mathrm{b}}$ - backward, and $\nu_{\text {effective }}=100 \mathrm{mV} \mathrm{s}^{-1}$.

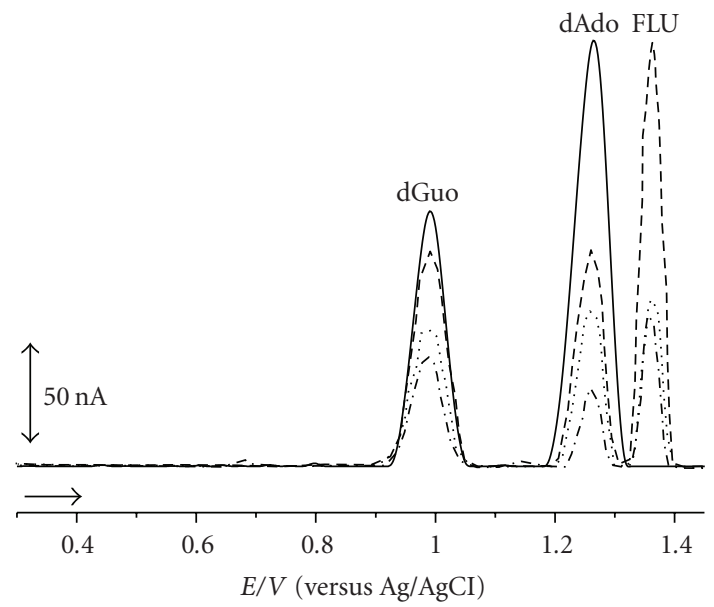

FIGURE 4: DP voltammograms baseline corrected in $\mathrm{pH} 4.50 .1 \mathrm{M}$ acetate buffer of: (solid line) $100 \mu \mathrm{g} \mathrm{mL}^{-1} \mathrm{dsDNA}$ and incubated solutions during (dashed line) $0 \mathrm{~h}$, (dotted line) $1 \mathrm{~h}$, and (dashdotted line) $3 \mathrm{~h}$ of $100 \mu \mathrm{g} \mathrm{mL}^{-1}$ DNA with $2 \mu \mathrm{M}$ FLU. Pulse amplitude-50 $\mathrm{mV}$, pulse width-70 $\mathrm{ms}$, and $\nu=5 \mathrm{mV} \mathrm{s}^{-1}$.

and causes DNA disruption or breakages. Therefore, the investigation and clarification of the interaction mechanism between FLU and DNA is very important.

The mechanism of interaction of FLU with dsDNA, Poly[A] and Poly[G], in incubated solutions or with the multilayer GCE modified as described in the Experimental (Section 2.4), was investigated.
3.2.1. DNA-Fludarabine Interaction in Incubated Solutions. In order to investigate the interaction between FLU and dsDNA, Figure 4, presents the DP voltammograms obtained, in $\mathrm{pH} 4.50 .1 \mathrm{M}$ acetate buffer, for FLU, one oxidation peak $1_{\mathrm{a}}$, at $E_{\mathrm{pa}}=+1.35 \mathrm{~V}$, and for dsDNA, two welldefined and separated peaks corresponding to the oxidation of desoxyguanosine (dGuo), at $E_{\mathrm{pa}}=+0.98 \mathrm{~V}$, and desoxyadenosine (dAdo), at $E_{\mathrm{pa}}=+1.25 \mathrm{~V}$, Figure 4 .

The interaction between FLU and dsDNA was studied in incubated solutions of $2 \mu \mathrm{M}$ FLU and $100 \mu \mathrm{g} \mathrm{mL}^{-1} \mathrm{dsDNA}$, in $\mathrm{pH} 4.50 .1 \mathrm{M}$ acetate buffer, and DP voltammograms recorded for different incubation times. Control solutions of $2 \mu \mathrm{M}$ FLU and $100 \mu \mathrm{g} \mathrm{mL}^{-1} \mathrm{dsDNA}$, in $\mathrm{pH} 4.50 .1 \mathrm{M}$ acetate buffer, were also prepared, and DP voltammograms recorded for the same incubation times. The GCE surface was cleaned between each measurement to avoid the blocking of the GCE surface by adsorption of the FLU and dsDNA.

The DP voltammograms obtained immediately after addition of FLU to dsDNA solution, showed three peaks corresponding to the oxidation of dsDNA purinic bases, dGuo, at $E_{\mathrm{pa}}=+0.98 \mathrm{~V}, \mathrm{dAdo}$, at $E_{\mathrm{pa}}=+1.25 \mathrm{~V}$, and FLU, at $E_{\mathrm{pa}}=+1.35 \mathrm{~V}$, Figure 4 . Increasing the incubation time, the peak current of dGuo and dAdo decreased, indicating that dsDNA structure was modified due to the interaction FLU-dsDNA by condensation and/or aggregation, which makes more difficult the access of the dsDNA bases to the electrode surface hindering their oxidation. However, no dsDNA oxidative damage caused by FLU occurred, as no peaks corresponding to the oxidation of 8-oxoGua or 2,8oxoAde, the oxidation products of dsDNA purinic bases, were observed in the DP voltammograms, Figure 4. 


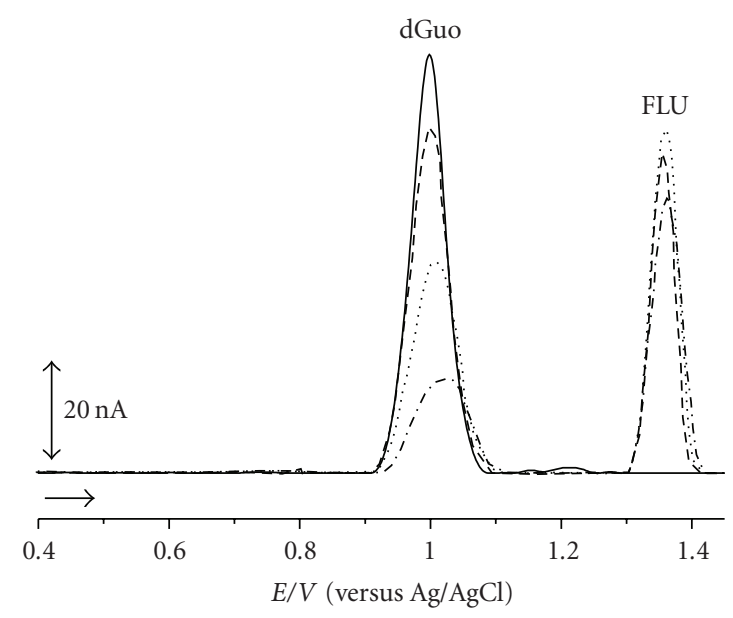

(a)

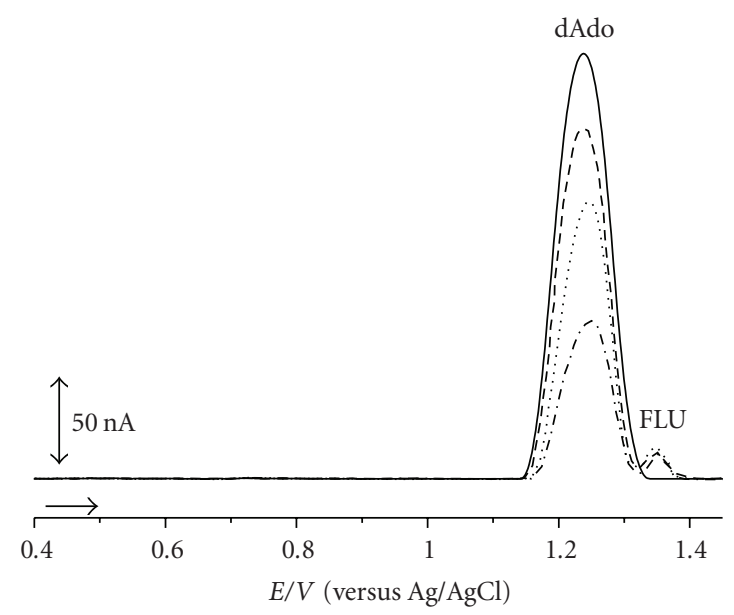

(b)

Figure 5: DP voltammograms baseline corrected in $\mathrm{pH} 4.50 .1 \mathrm{M}$ acetate buffer of $100 \mu \mathrm{g} \mathrm{mL}^{-1}$ : (a) Poly[G] and (b) Poly[A] (solid line) before and after incubation with $5 \mu \mathrm{M}$ FLU during (dashed line) $0 \mathrm{~h}$, (dotted line) $1 \mathrm{~h}$, and (dash-dotted line) $3 \mathrm{~h}$. Pulse amplitude-50 mV, pulse width-70 $\mathrm{ms}$, and $v=5 \mathrm{mV} \mathrm{s}^{-1}$.

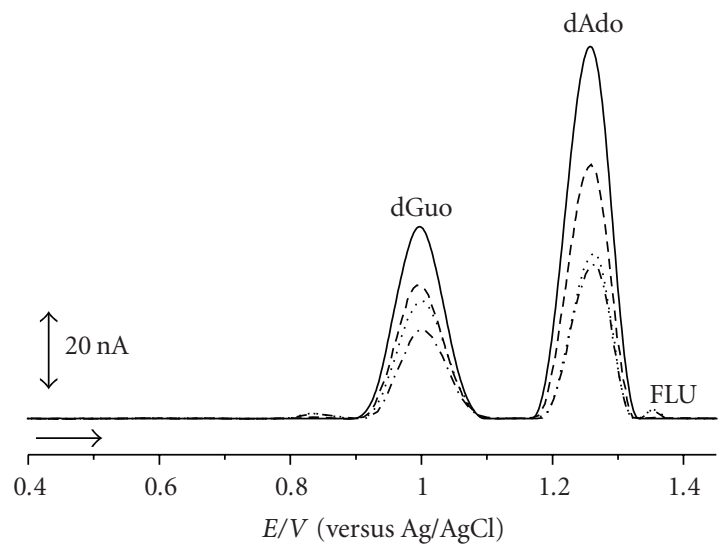

FIGURE 6: DP voltammograms baseline corrected in $\mathrm{pH} 4.50 .1 \mathrm{M}$ acetate buffer with dsDNA-electrochemical biosensors (solid line) before and after incubation during (dashed line) $5 \mathrm{~min}$, (dotted line) $10 \mathrm{~min}$, and (dash dotted line) $15 \mathrm{~min}$ in a solution of $50 \mu \mathrm{M}$ FLU. Pulse amplitude- $50 \mathrm{mV}$, pulse width- $70 \mathrm{~ms}$, and scan rate $\nu=5 \mathrm{mV} \mathrm{s}^{-1}$.

To clarify the interaction of FLU and dsDNA, experiments were also carried out in incubated solutions of $5 \mu \mathrm{M} \mathrm{FLU}$ and $100 \mu \mathrm{g} \mathrm{mL}^{-1}$ purinic base solutions, poly[G] or poly[A], in pH $4.50 .1 \mathrm{M}$ acetate buffer, Figure 5. DP voltammograms showed similar results as with dsDNA, confirming the decrease of the oxidation peaks of dGuo and dAdo and no oxidative damage, as no peaks corresponding to the oxidation products of guanine, 8 -oxoGua, and adenine, 2,8-oxoAde, occurred.

3.2.2. In Situ DNA-Fludarabine Interaction. Multilayer dsDNA-, Poly[G]-, and Poly[A]-electrochemical biosensors were prepared and used to investigate the in situ DNAfludarabine interaction. The electrochemical biosensor surface was covered by a multilayer to make sure that the undesired adsorption of FLU on GCE could not occur. The dsDNA-, Poly[G]-, and Poly[A]-electrochemical biosensors enable the identification of the in situ interaction with time, besides the advantage of low cost, fast response time, simple design, and high detection limit.

The dsDNA-electrochemical biosensor was prepared, Section 2.4, incubated in $50 \mu \mathrm{M}$ FLU solution for different times, 5, 10, and $15 \mathrm{~min}$, and transferred to supporting electrolyte buffer solution. In order to remove unbounded FLU, the dsDNA-electrochemical biosensor was carefully washed with deionized water before being transferred to pH $4.50 .1 \mathrm{M}$ acetate buffer where the DP voltammograms were recorded, Figure 6. In this way, the observed peaks in the DP voltammograms can only be caused by the interaction between dsDNA and FLU. As expected, dGuo and dAdo, and a very small FLU oxidation peaks were also obtained, Figure 6. After each measurement, the dsDNA film was removed from the electrode surface and the experiments were always performed with a newly prepared biosensor. The results showed that dGuo and dAdo oxidation peaks decreased with increasing incubation time in the FLU solution. This is caused by modifications in the dsDNA morphological structure and strand breaks, due to the interaction with FLU. No oxidation peaks for 8oxoGua and 2,8-oxoA, the dsDNA purinic bases oxidation products, were observed, so there was no DNA oxidative damage.

Polynucleotides biosensors, Poly $[\mathrm{G}]$ - and Poly[A]electrochemical biosensors, were prepared, Section 2.4, and incubated in $50 \mu \mathrm{M}$ FLU in $\mathrm{pH} 4.50 .1 \mathrm{M}$ acetate buffer for different times, in order to shine more information on the interaction between dsDNA and FLU, Figure 7. 


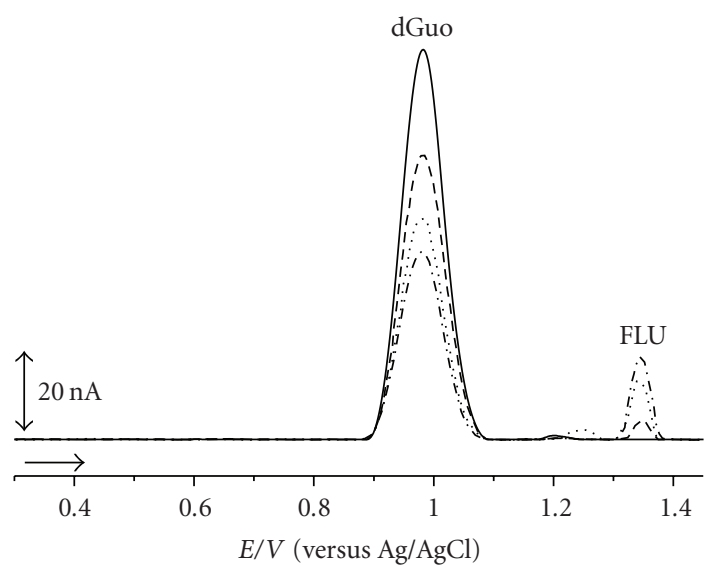

(a)

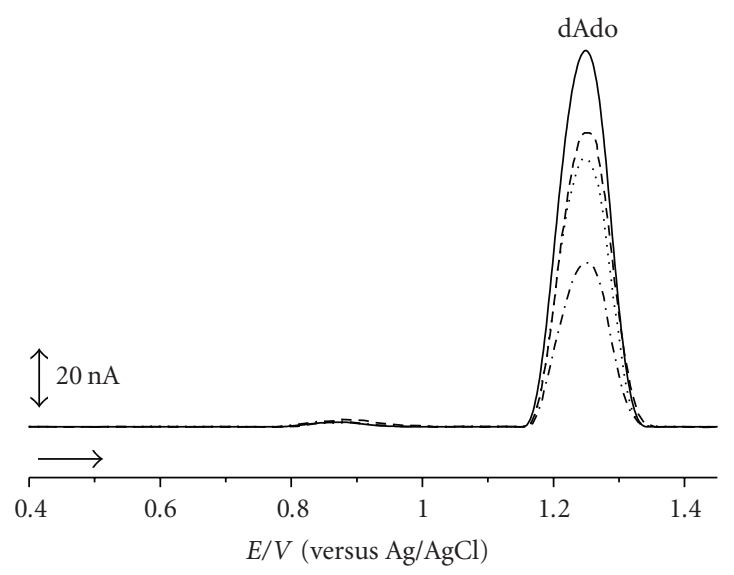

(b)

FIGURE 7: DP voltammograms baseline corrected in pH 4.5 0.1 M acetate buffer with (a) Poly[G]- and (b) Poly[A]-electrochemical biosensors (solid line) before and after incubation during (dashed line) $5 \mathrm{~min}$, (dotted line) $10 \mathrm{~min}$, and (dash-dotted line) $15 \mathrm{~min}$ in a solution of $50 \mu \mathrm{M}$ FLU. Pulse amplitude- $50 \mathrm{mV}$, pulse width- $70 \mathrm{~ms}$ and scan rate $v=5 \mathrm{mV} \mathrm{s}^{-1}$.

Poly $[\mathrm{G}]$-electrochemical biosensor, after being transferred to $\mathrm{pH} 4.50 .1 \mathrm{M}$ acetate buffer, showed two peaks one for FLU and the other for poly[G], corresponding the oxidation of dGuo, at $E_{\mathrm{pa}}=+0.98 \mathrm{~V}$, which decreased with increasing incubation time, and no oxidation peak for 8oxoGua was observed, Figure $7($ a).

Poly[A]-electrochemical biosensor, after being transferred to $\mathrm{pH} 4.50 .1 \mathrm{M}$ acetate buffer, showed two peaks one for FLU and the other for poly[A], corresponding the oxidation of dAdo, at $E_{\mathrm{pa}}=+1.25 \mathrm{~V}$, which decreased with increasing incubation time, and no oxidation peak for 2,8oxoA was observed, Figure 7(b).

These experiments using polyhomopurinenucleotide single-stranded sequences, poly $[\mathrm{G}]$ - and poly[A]-electrochemical biosensors, confirm the results obtained using the dsDNA-electrochemical biosensor.

\section{Conclusion}

The electrochemical behaviour of fludarabine was investigated on the GCE in different aqueous buffer solutions using CV, DP, and SW voltammetry. The oxidation mechanism of fludarabine is irreversible, $\mathrm{pH}$ dependent and occurs with one electrode and one proton transfer. The diffusion coefficient $D_{\mathrm{FLU}}=1.71 \times 10^{-6} \mathrm{~cm}^{2} \mathrm{~s}^{-1} \cdot 10^{-6} \mathrm{~cm}^{2} \mathrm{~s}^{-1}$ was determined. In the electroanalytical determination of FLU, the values of LOD $=0.28 \mu \mathrm{M}$ and $\mathrm{LOQ}=0.94 \mu \mathrm{M}$ were found.

The mechanism of interaction of FLU with dsDNA, poly[A] and poly[G], in incubated solutions or with multilayer GC modified electrodes, clearly showed, using the concentrations chosen, that fludarabine-DNA interaction caused morphological changes and strand breaks in the dsDNA structure in a time-dependent manner, but no DNA oxidative damage.

\section{Acknowledgments}

Financial support from Fundação para a Ciência e Tecnologia (FCT), Projects PTDC/QUI/65732/2006 and PTDC/QUI/ 098562/2008, POCI (cofinanced by the European Community Fund FEDER), CEMUC-R (Research Unit 285), and The Scientific and Technological Research Council of Turkey (TUBITAK)-International Postdoctoral Research Fellowship Programme (BIDEB) (H.E.S.) are gratefully acknowledged.

\section{References}

[1] C. Tondini, M. Balzarotti, I. Rampinelli et al., "Fludarabine and cladribine in relapsed/refractory low-grade nonHodgkin's lymphoma: a phase II randomized study," Annals of Oncology, vol. 11, no. 2, pp. 231-233, 2000.

[2] S. J. Wright, L. E. Robertson, S. O'Brien, W. Plunkett, and M. J. Keating, "The role of fludarabine in hematological malignancies," Blood Reviews, vol. 8, no. 3, pp. 125-134, 1994.

[3] C. O. Rodriguez Jr., W. Plunkett, M. T. Paff et al., "Highperformance liquid chromatography method for the determination and quantitation of arabinosylguanine triphosphate and fludarabine triphosphate in human cells," Journal of Chromatography B, vol. 745, no. 2, pp. 421-430, 2000.

[4] T. Yamauchi and T. Ueda, "Simple and sensitive method for quantification of fludarabine triphosphate intracellular concentration in leukemic cells using isocratic liquid chromatography," Journal of Chromatography B, vol. 799, no. 1, pp. 81-86, 2004.

[5] A. Kemena, M. Fernandez, J. Bauman, M. Keating, and W. Plunkett, "A sensitive fluorescence assay for quantitation of fludarabine and metabolites in biological fluids," Clinica Chimica Acta, vol. 200, no. 2-3, pp. 95-106, 1991.

[6] G. Misztal and B. Paw, "Determination of fludarabine phosphate in human plasma using reversed phase highperformance liquid chromatography," Pharmazie, vol. 51, no. 10, pp. 733-734, 1996. 
[7] R. Ficarra, M. L. Calabrò, S. Tommasini et al., "Determination of fludarabine in a pharmaceutical formulation by LC," Journal of Pharmaceutical and Biomedical Analysis, vol. 21, no. 5, pp. 1077-1081, 1999.

[8] L. D. Vainchtein, H. Rosing, J. H. M. Schellens, and J. H. Beijnen, "A new, validated HPLC-MS/MS method for the simultaneous determination of the anti-cancer agent capecitabine and its metabolites: 5'-deoxy-5- fluorocytidine, 5'-deoxy-5fluorouridine, 5-fluorouracil and 5-fluorodihydrouracil, in human plasma," Biomedical Chromatography, vol. 24, no. 4, pp. 374-386, 2010.

[9] N. De-Los-Santos-Álvarez, M. J. Lobo-Castañón, A. J. Miranda-Ordieres, and P. Tuñón-Blanco, "Electrocatalytic adsorptive voltammetry for fludarabine determination in urine," Analytica Chimica Acta, vol. 504, no. 2, pp. 271-277, 2004.

[10] F. Jelen, M. Fojta, and E. Paleček, "Voltammetry of native double-stranded, denatured and degraded DNAs," Journal of Electroanalytical Chemistry, vol. 427, no. 1-2, pp. 49-56, 1997.

[11] A. M. Oliveira-Brett, J. A. P. Piedade, L. A. Silva, and V. C. Diculescu, "Voltammetric determination of all DNA nucleotides," Analytical Biochemistry, vol. 332, no. 2, pp. 321329, 2004.

[12] X. Cai, G. Rivas, H. Shirashi et al., "Electrochemical analysis of formation of polynucleotide complexes in solution and at electrode surfaces," Analytica Chimica Acta, vol. 344, no. 1-2, pp. 65-76, 1997.

[13] A. M. Chiorcea-Paquim, O. Corduneanu, S. C. B. Oliveira, V. C. Diculescu, and A. M. Oliveira-Brett, "Electrochemical and AFM evaluation of hazard compounds-DNA interaction," Electrochimica Acta, vol. 54, no. 7, pp. 1978-1985, 2009.

[14] C. M. A. Brett and A. M. Oliveira-Brett, Electrochemistry, Principles, Methods and Applications, Oxford University Press, Oxford, UK, 1993.

[15] 2010, http://www.hbcpretbase.com/HandbookofChemistryandPhysics.

[16] C. M. Riley and T. W. Rosanske, Development and Validation of Analytical Methods, Elsevier Science, New York, NY, USA, 1996.

[17] M. E. Swartz and I. S. Krull, Analytical Method Development and Validation, Marcel Dekker, New York, NY, USA, 1997. 


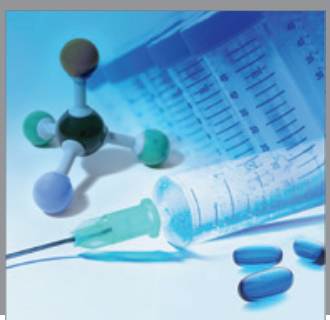

International Journal of

Medicinal Chemistry

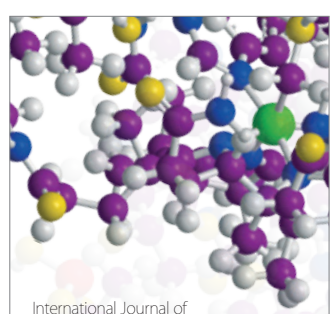

Carbohydrate Chemistry

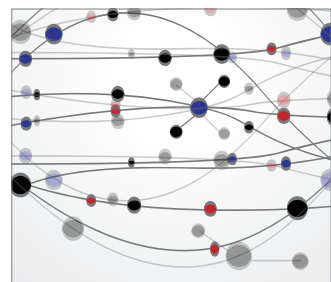

The Scientific World Journal
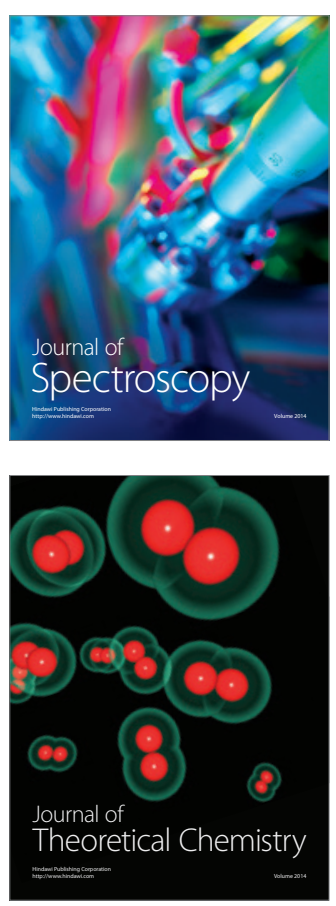
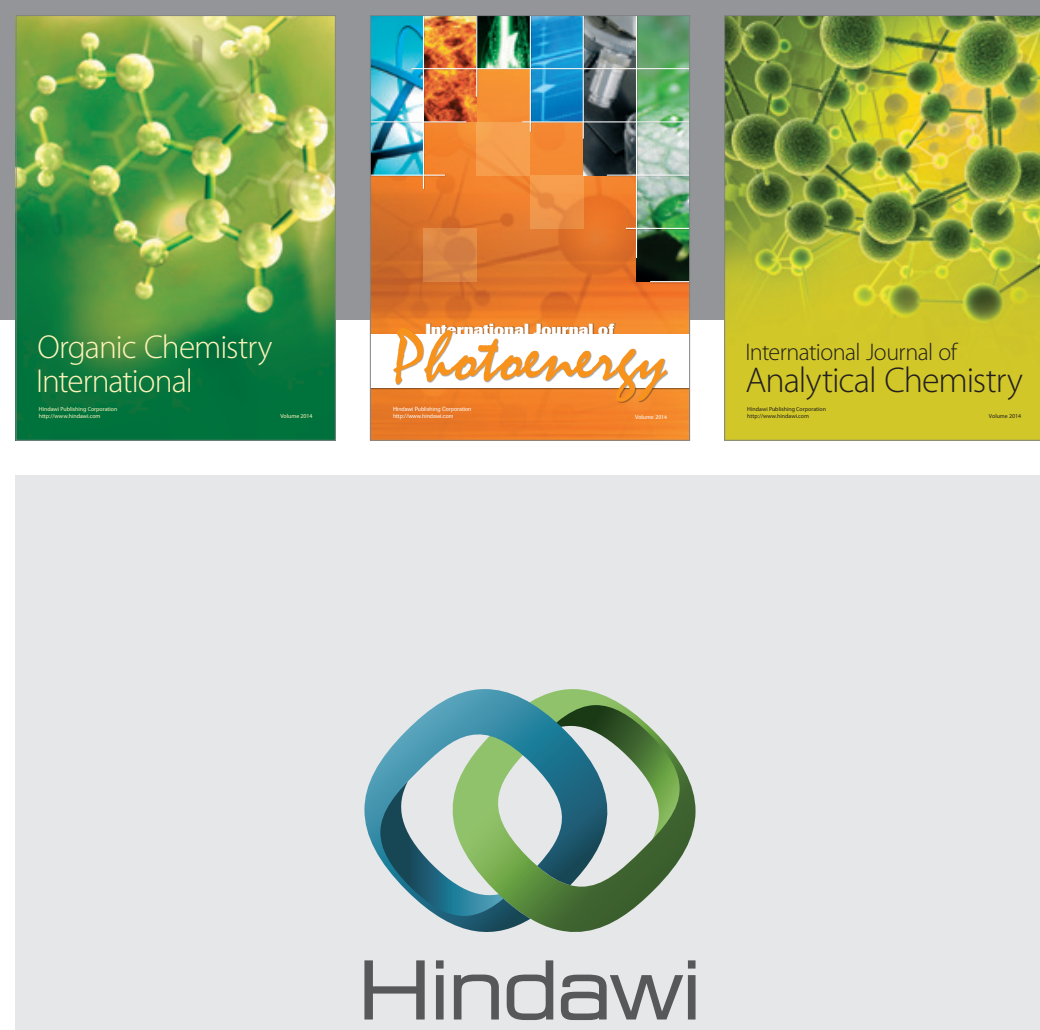

Submit your manuscripts at

http://www.hindawi.com
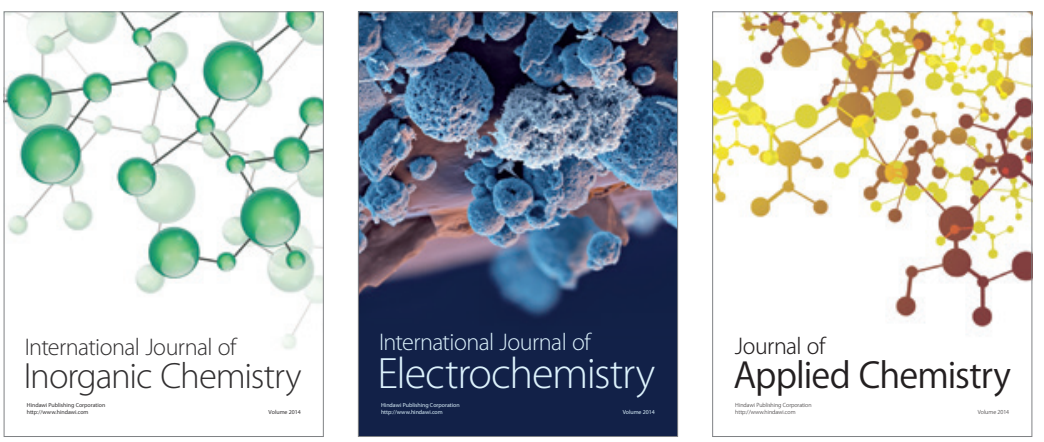

Journal of

Applied Chemistry
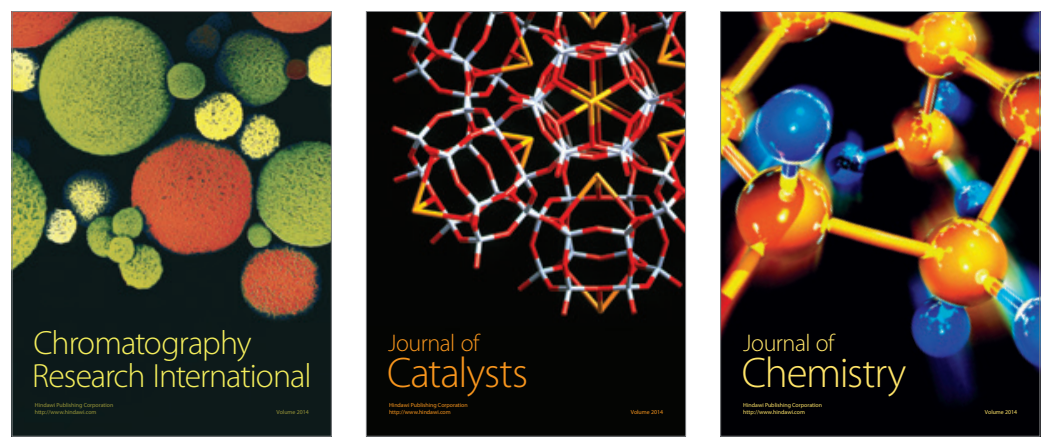
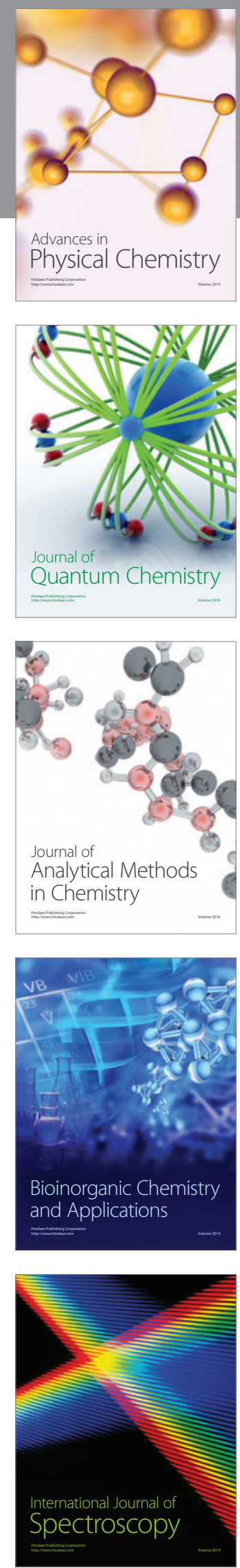